\title{
Faktor-Faktor yang Memengaruhi Pengetahuan Anak pada Lagu Daerah Kalimantan
}

\author{
Factors Affecting Children's Knowledge on the Regional Song of Kalimantan
}

Zamrud Whidas Pratama*, Program Studi Etnomusikologi, Fakultas Ilmu Budaya, Universitas Mulawarman. Email: zamrudwhidas@fib.unmul.ac.id

Famala Eka Sanhadi Rahayu, Program Studi Sastra Inggris, Fakultas Ilmu Budaya, Universitas Mulawarman. Email: m.difa2013@gmail.com

Received:

9 Agustus 2021

Accepted:

15 September 2021

Published:

30 Oktober 2021

Keywords:

factor-factor, knowledge,

traditional song

Kata kunci:

faktor-faktor, pengetahuan, lagu daerah

\begin{abstract}
:
Knowledge of elementary school-aged children in Kalimantan folk songs is a severe problem because children's knowledge is one of the factors that can affect the achievement of local song preservation. So that information is needed regarding surveys about what factors influence children's knowledge of Kalimantan folk songs. The theory used in this study is the theory of factors that influence learning. This study aims to determine the factors that influence children's knowledge of folk songs, especially Kalimantan. This study uses survey research with quantitative descriptive methods, namely, conducting field surveys. The sample of this study was 158 students, namely grades $5 A$ and $5 B$ of Elementary School 005 Samarinda, totaling 40 students, and classes 5A, 5B, and 5C of Elementary School 007 Samarinda totaling 118 students. The results of data analysis show that there are internal and external factors. The internal factor is that students listen to more popular songs because popular songs are currently packaged with unique and various videos. Even the advertisements that they usually hear contain many lyrics from popular songs today so that children are more interested and interested in listening to popular songs than folk songs. Another internal factor is when students do gymnastics together, the songs played are popular dangdut songs today. External factors indicate that the teacher's lack of knowledge about the folk songs of East Kalimantan.
\end{abstract}

\begin{abstract}
Abstrak:
Pengetahuan anak-anak usia Sekolah Dasar (SD) pada lagu daerah Kalimantan merupakan permasalahan yang cukup serius, dikarenakan pengetahuan anak-anak merupakan salah satu faktor yang dapat mempengaruhi tercapainya pelestarian lagu daerah. Sehingga diperlukan informasi mengenai survei tentang apa saja faktorfaktor yang mempengaruhi pengetahuan anak pada lagu daerah Kalimantan. Teori yang digunakan dalam penelitian ini adalah teori faktor yang mempengaruhi belajar. Penelitian ini bertujuan untuk mengetahui faktor yang mempengaruhi pengetahuan anak terhadap lagu daerah khususnya Kalimantan. Penelitian ini menggunakan penelitian survei dengan metode deskriptif kwantitatif yakni melakukan survei lapangan. Sempel penelitian ini adalah 158 siswa, yaitu kelas 5A dan 5B Sekolah Dasar Negeri 005 Samarinda berjumlah 40 siswa, dan kelas 5A, 5B, dan 5C Seklah Dasar Negeri 007 Samarinda berjumlah 118 siswa. Hasil analisis data menunjukan bahwa terdapat faktor internal dan eksternal. Faktor internal adalah siswa lebih banyak mendengarkan lagu populer karena lagu populer saat ini dikemas dengan video yang unik dan bermacam-macam. Bahkan iklan-iklan yang biasa mereka dengar banyak gubahan lirik dari lagu-lagu populer saat ini, sehingga anak-anak lebih tertarik dan berminat untuk mendengarkan lagu populer daripada lagu daerah. Faktor internal lain adalah ketika siswa melakukan kegiatan senam bersama, lagu yang diputar adalah lagu-lagu dangdut populer masa kini. Faktor
\end{abstract}


eksternal menunjukan bahwa kurangnya pengetahuan guru mengenai lagu daerah Kalimantan Timur.

\section{Citation:}

Pratama, Z. W., \& Rahayu, F. E. S. (2021). Faktor-Faktor yang memengaruhi Pengetahuan Anak pada Lagu Daerah Kalimantan Jurnal Mebang: Kajian Budaya Musik dan Pendidikan Musik, 2(1), 63-68. https://doi.org/10.30872/mebang.v1i2.15

\section{Pendahuluan}

Sangat menyedihkan sekali apabila melihat beberapa fakta yang seakan lagu-lagu daerah pada saat ini hanya dijadikan sebagai simbol saja. Generasi muda yang saat ini kebanyakan hanya mengikuti trend yang hanya menyukai dan menyanyikan lagu-lagu pop dan mancanegara yang cenderung bernuansa cinta dan melupakan lagu-lagu daerah. Seolah tidak ada rasa memiliki terhadap lagu-lagu daerah yang dimiliki, sehingga disaat lagu daerah di klaim oleh Negara atau bangsa lain baru akan mempunyai rasa kepedulian untuk memiliki akan sebuah budaya bangsa yang harus dijaga dan dilestarikan. Dari segi makna syair dan fungsi/peranan lagu daerah lebih mempunyai filosofi dibandingkan dengan lagu Jazz, Pop, Metal dan Rock. Tetapi seakan generasi muda tidak peduli dengan semua itu. Padahal lagu daerah merupakan warisan nenek moyang dan para Wali Songo dahulu kala. Lagu daerah sebagai salah satu asset budaya bangsa ini harus terus dijaga dan dilestarikan. Slameto (2003, p. 180), bahwa "Minat tidak dibawa sejak lahir, melainkan diperoleh kemudian. Minat terhadap sesuatu merupakan hasil belajar dan menyokong belajar selanjutnya." Hal ini menggambarkan bahwa minat dapat ditumbuhkan dan dikembangkan.

Minat tidak akan muncul dengan sendirinya secara tiba-tiba dari dalam diri individu. Minat dapat timbul pada diri seseorang melalui proses. Dengan adanya perhatian dan interaksi dengan lingkungan, maka minat tersebut dapat berkembang. Munculnya minat ini biasanya ditandai dengan adanya dorongan, perhatian, rasa senang, kemampuan, dan kecocokan atau kesesuaian. Timbulnya minat seseorang disebabkan oleh beberapa hal, yaitu rasa tertarik atau rasa senang, perhatian dan kebutuhan. Minat timbul karena perasaan senang serta tendensi yang dinamis untuk berperilaku atas dasar ketertarikan seseorang pada jenis-jenis kegiatan tertentu. Perasaan senang seseorang akan menimbulkan dorongan-dorongan dalam dirinya untuk segera beraktifitas. Faktor-faktor yang mempengaruhi minat anak, antara lain faktor internal dan eksternal.

Faktor internal adalah sesuatu yang membuat siswa berminat yang datangnya dari dalam diri. Menurut Reber dalam Syah (2005, p. 151) faktor internal tersebut adalah pemusatan perhatian, keingintahuan, motivasi, dan kebutuhan". Faktor eksternal Faktor eksternal adalah sesuatu yang membuat siswa berminat yang datangnya dari luar diri, seperti: dorongan dari orang tua, dorongan dari guru, rekan, tersedianya prasarana dan sarana atau fasilitas, dan keadaan lingkungan. Sebagai pewaris kebudayaan, sangat disayangkan apabila anak-anak sekolah yang tidak mengenal lagu daerah terutama lagu daerah Kalimantan. Minat anak-anak usia sekolah dasar (SD) terhadap lagu daerah Kalimantan merupakan permasalahan yang cukup serius, dikarenakan minat dan pengetahuan anak-anak merupakan salah satu faktor yang dapat mempengaruhi tercapainya pelestarian lagu daerah. Oleh karena itu, peneliti ingin mendeskripsikan faktor-faktor yang mempengaruhi minat dan pengetahuan anak tentang lagu daerah Kalimantan. 


\section{Metode}

Penelitian tentang minat dan pengetahuan anak terhadap lagu daerah merupakan penelitian deskriptif kuantitatif dengan jenis pendekatan survei. Survei diadakan untuk memperoleh gambaran umum tentang karakteristik populasi. Dalam penelitian survei, informasi dikumpulkan dari responden melalui kuesioner (Efendi, 2012, p. 3). Ciri khas penelitian survei adalah data dikumpulkan dari responden yang banyak jumlahnya dengan menggunakan kuesioner (Efendi, 2012, p. 24). Dalam penelitian survei, populasi biasanya berjumlah besar sehingga peneliti perlu menentukan sampel penelitian (Efendi, 2012:26). Jika sebuah populasi kurang dari 100, maka tidak diperlukan penentuan sampel penelitian. Penelitian survei berusaha memaparkan secara kualitatif kecenderungan, sikap, atau opini dari suatu populasi tertentu dengan meneliti satu sampel dari populasi tersebut. Jenis penelitian survei adalah penelitian yang bertujuan memperoleh informasi dari sekelompok orang, dalam hal ini sampel, melalui kuesioner yang diberikan kepada responden. Untuk memperoleh data penelitian melalui kuesioner, penelitian akan diadakan di SD 005 dan SD 007 Samarinda Kota. Penelitian akan dilakukan pada bulan Oktober-November 2018 dimana waktu tersebut dirasa sesuai dan tidak mengganggu proses pembelajaran siswa di sekolah. Jumlah populasi penelitian ini adalah 158 anak. Analisis data merupakan kegiatan setelah data dari seluruh responden atau sumber data lain terkumpul. Dalam penelitian ini, untuk mendapatkan data minat dan pengetahuan anak terhadap lagu daerah Kalimantan Timur digunakan angket atau kuesioner. Data penelitian ini dianalisis dengan teknik deskriptif kuantitatif yang dilengkapi dengan tabel dan grafik. Analisis data deskriptif dalam penelitian adalah untuk mengetahui gambaran hasil keseluruhan faktor-faktor yang mempengaruhi siswa terhadap lagu daerah Kalimantan Timur.

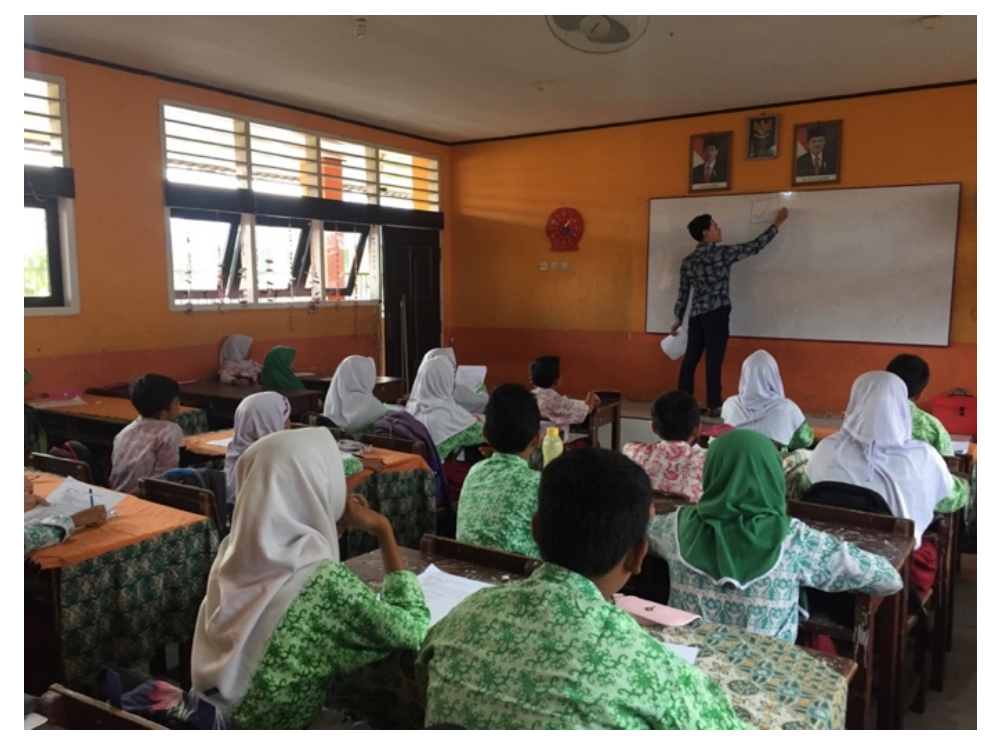

Gambar 1. Siswa SDN 007 Samarinda

\section{Hasil dan Pembahasan}

Berdasarkan hasil penelitian mengenai minat dan pengetahuan anak terhadap lagu daerah 
Kalimantan Timur, dapat diketahui bahwa sebagian besar responden memiliki minat yang tinggi terhadap lagu daerah namun memiliki tingkat pengetahuan yang rendah terhadap lagu daerah Kalimantan Timur. Ada beberapa faktor yang mempengaruhi hal ini. Selanjutnya Faktor-faktor yang mempengaruhi minat anak, antara lain adalah faktor nternal dan faktor eksternal. Faktor Internal adalah sesuatu yang membuat siswa berminat yang datangnya dari dalam diri. Menurut Reber dalam Syah (2005, p. 151) faktor internal tersebut adalah pemusatan perhatian, keingintahuan, motivasi, dan kebutuhan. Relevan dengan teori yang dipaparkan diatas, temuan penelitian bahwa siswa lebih banyak mendengarkan lagu populer karena lagu populer saat ini dikemas dengan video yang unik dan bermacam-macam, bahkan iklan-iklan yang biasa mereka dengar banyak gubahan lirik dari lagu-lagu populer saat ini, sehingga anak-anak lebih tertarik dan berminat untuk mendengarkan lagu populer daripada lagu daerah. Temuan penelitian selanjutnya, bahwa pada saat siswa melakukan kegiatan senam bersama, lagu yang diputar adalah lagu-lagu dangdut populer masa kini seperti lagu Syantik yang dipopulerkan oleh Siti badriah dan lagu-lagu semacamnya.

Selanjutnya faktor yang mempengaruhi minat adalah faktor eksternal. Faktor eksternal adalah sesuatu yang membuat siswa berminat yang datangnya dari luar diri, seperti dorongan dari orang tua, dorongan dari guru, rekan, tersedianya prasarana dan sarana atau fasilitas, dan keadaan lingkungan. Hal tersebut relevan dengan teori yang dipaparkan diatas yaitu karena kurangnya paparan terhadap lagu daerah Kalimantan Timur. Yang dimaksud dengan paparan dalam hal ini adalah, anak jarang mempelajari, atau mendengar lagu-lagu daerah yang berasal dari Kalimantan Timur. Hal ini berkaitan dengan kurikulum yang diajarkan disekolah dan juga kebijakan daerah mengenai pembelajaran lagu daerah.

Faktor eksternal berikutnya adalah kurangnya pengetahuan guru mengenai lagu daerah Kalimantan Timur. Bukan hal yang dapat dipungkiri bahwa anak-anak yang masih duduk dibangku sekolah dasar belum memiliki kemandirian dalam belajar yang penuh. Sebagian besar anak masih menjadikan gurunya sebagai sumber pengetahuan yang pertama dan utama. Sehingga ketika guru yang mengajar memiliki pengetahuan yang terbatas mengenai lagu daerah Kalimantan timur, hal ini tentunya akan berimbas kepada anak-anak didiknya. Oleh karena itu, pendampingan guru kesenian di sekolah dasar juga menjadi hal yang penting untuk menjadi solusi dalam permasalahan ini.

\section{Simpulan}

Berdasarkan hasil penelitian yang diperoleh melalui survei terhadap anak-anak mengenai minat dan pengetahuan mereka terhadap lagu daerah Kalimantan Timur dapat disimpulkan bahwa faktor-faktor yang mempengaruhi pengetahuan anak terhadap lagu daerah Kalimantan meliputi faktor internak dan eksternal. Faktor internal bahwa siswa lebih banyak mendengarkan lagu populer karena lagu populer saat ini dikemas dengan video yang unik dan bermacam-macam, bahkan iklan-iklan yang biasa mereka dengar banyak gubahan lirik dari lagu-lagu populer saat ini, sehingga anak-anak lebih tertarik dan berminat untuk mendengarkan lagu populer daripada lagu daerah. Temuan penelitian selanjutnya, bahwa pada saat siswa melakukan kegiatan senam bersama, lagu yang diputar adalah lagu-lagu dangdut populer masa kini seperti lagu Syantik yang dipopulerkan oleh Siti badriah dan lagulagu semacamnya. Selanjutnya faktor eksternal. Faktor eksternal adalah yaitu kurangnya paparan terhadap lagu daerah Kalimantan Timur. Yang dimaksud dengan paparan dalam hal ini adalah anak jarang mempelajari, atau mendengar lagu-lagu daerah yang berasal dari 
Kalimantan Timur. Hal ini berkaitan dengan kurikulum yang diajarkan disekolah dan juga kebijakan daerah mengenai pembelajaran lagu daerah. Faktor eksternal berikutnya adalah kurangnya pengetahuan guru mengenai lagu daerah Kalimantan Timur. Bukan hal yang dapat dipungkiri bahwa anak-anak yang masih duduk dibangku sekolah dasar belum memiliki kemandirian dalam belajar yang penuh. Sebagian besar anak masih menjadikan gurunya sebagai sumber pengetahuan yang pertama dan utama sehingga ketika guru yang mengajar memiliki pengetahuan yang terbatas mengenai lagu daerah Kalimantan timur, hal ini tentunya akan berimbas kepada anak-anak didiknya. Oleh karena itu, pendampingan guru kesenian di sekolah dasar juga menjadi hal yang penting untuk menjadi solusi dalam permasalahan ini.

\section{Referensi}

Salam, A. (2008). Manajemen Personalia (Manajemen Sumber Daya Manusia). Ghalia: Jakarta. Sobur, A. (2003). Psikologi Umum. Bandung: Pustaka Setia.

Sobur, A. (2013). Filasafat Komunikasi. Bandung: PT Remaja Rosdakarya.

Ali, M. (2010). Metodologi dan Aplikasi Riset Pendidikan. Bandung: Pustaka Cendikia Utama. Arikunto, S. (2002). Metodologi Penelitian Suatu Pendekatan Proposal. Jakarta: PT. Rineka Cipta.

Arikunto, S. (2006). Metode Penelitian Kualitatif. Jakarta: Bumi Aksara.

Banoe, P. (2003). Kamus Musik. Yogyakarta: Kanisius.

Chaplin, C. P. (1995). Kamus Lengkap Psikologi. Jakarta: Rajawali Pers.

Crow, L. \& Crow, A. (1989). Psychologi Pendidikan. Yogyakarta: Nur Cahaya.

Djaali. (2007). Psikologi Pendidikan. Jakarta: Bumi Aksara.

Effendi. (2012). Metode Penelitian Survei. Jakarta: LP3ES.

Gie, T. L. (1995). Cara Belajar yang Evisien. Yogyakarta: Liberti.

Mappiare, A. (1982). Psikologi remaja. Surabaya: Usaha Nasional.

Muhibbin, S. (2005). Psikologi Belajar. Jakarta: Raya Grafindo Perkasa.

Notoatmodjo, S. (2003). Pendidikan Dan Perilaku Kesehatan. Jakarta: Rineka Cipta.

Reber, S.A. \& Reber, S.E. (2010). Kamus Psikologi. Yogyakarta: Pustaka Pelajar.

Pratama, Z. W., Setyoko, A., \& Arozaq, F. Y. (2021). Ornamentasi Vokal pada Tarsul Kutai Kartanegara: Jurnal Mebang: Kajian Budaya Musik dan Pendidikan Musik, 1(1), 25-34. https://doi.org/10.30872/mebang.v1i1.3

Prier, K. S. J. (2011). Kamus Musik. Yogyakarta: Pusat Musik Liturgi.

Slameto. (2010). Belajar dan Faktor-Faktor yang Mempengaruhinya. Jakarta: PT. Rineka Cipta.

Syah, M. (2006). Psikologi Pendidikan Dengan Pendekatan Baru. Bandung: Remaja Rosdakarya. 
Faktor-Faktor yang Mempengaruhi Pengetahuan Anak pada Lagu Daerah Kalimantan 